\title{
Hydrothermal Method for Preparing Calcium Phosphate Monoliths
}

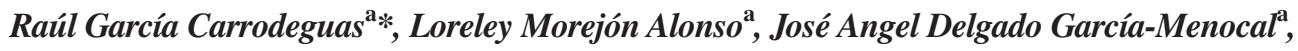 \\ Lizette Morejón Alonso a , María Pau Ginebra Molins ${ }^{\mathrm{b}}$, Salvador Martínez, Manent ${ }^{\mathrm{c}}$, \\ Javier Gil Mur ${ }^{\mathrm{b}}$,Jorge Toledo Pérez, ${ }^{\mathrm{a}}$ José Antonio Planell Estany ${ }^{\mathrm{b}}$ \\ ${ }^{\mathrm{a}}$ Centro de Biomateriales, Universidad de La Habana, \\ A.P. 6130, 10600 C. Habana, Cuba \\ ${ }^{\mathrm{b}}$ Centre de Recerca en Enginyeria Biomèdica, \\ Diagonal 647, pabelló E. 08028 Barcelona, Spain \\ ${ }^{\mathrm{c}}$ Departament de Cristallografia, Mineralogia i Dipòsits Minerals, Facultat de Geologia, \\ Universitat de Barcelona, Martí i Franquès s/n, 08028 Barcelona, Spain
}

Received: August 30, 2002; Revised: April 5, 2003

\begin{abstract}
A new hydrothermal route for preparing biphasic calcium phosphate monoliths is proposed. Firstly, a slurry of $\beta$-tricalcium phosphate/ortho-phosphoric acid $\left(\beta-\mathrm{TCP} / \mathrm{H}_{3} \mathrm{PO}_{4}\right)$ is cast into the desired final shape and size to obtain a block composed of dicalcium phosphate dihydrate (DCPD) and $\beta$-TCP. This block is then treated in $1.0 \mathrm{M} \mathrm{Na}_{2} \mathrm{HPO}_{4}$ at $60{ }^{\circ} \mathrm{C}$ in order to hydrolyze the DCPD into $\mathrm{Ca}_{10-\mathrm{x}}\left(\mathrm{HPO}_{4}\right)_{\mathrm{x}}(\mathrm{PO} 4)_{6-\mathrm{x}}(\mathrm{OH})_{2-\mathrm{x}}(\mathrm{CDHA})$ and $\mathrm{Ca}_{8} \mathrm{H}_{2}\left(\mathrm{PO}_{4}\right)_{6} \cdot 5 \mathrm{H}_{2} \mathrm{O}(\mathrm{OCP})$. The result is a monolithic piece which preserves the initial shape and size, but which is composed instead of CDHA, OCP, and $\beta$-TCP. During the initial stage, when the $\mathrm{pH}$ is slightly alkaline, the product of DCPD hydrolysis is CDHA. However, when a neutral or slightly acidic $\mathrm{pH}$ is reached OCP is formed. Test samples processed by this method showed complete conversion of DCPD into CDHA and OCP after $112 \mathrm{~h}$ of hydrolysis, and with a compressive strength of $16.2 \mathrm{MPa}$, similar to cancellous bone.
\end{abstract}

Keywords: dicalcium phosphate dihydrate, calcium deficient hydroxyapatite, octacalcium phosphate, $\beta$-tricalcium phosphate, calcium phosphate cement, calcium phosphate

\section{Introduction}

Nowadays, calcium phosphate monoliths of varying chemical and phase compositions and different porosities are widely used in dental, maxilla-facial, and orthopaedic surgeries for bone repairs and remodelling. The standard procedure for their preparation is to mould a powder of calcium phosphate, with the desired composition, into the required shape and size, followed by sintering at temperatures over $950{ }^{\circ} \mathrm{C}^{1}$. Pressing (uniaxial or isostatic) ${ }^{2-5}$, slip- ${ }^{6-10}$ or gel-casting ${ }^{11,12}$ are the moulding methods commonly used. Pressure gradients caused by particle-particle and particlemould wall friction forces; large drying and sintering shrinkages; and toxic and expensive raw materials, limit the application of the above mentioned moulding procedures to small and simple-shaped parts (discs, cylinders, or prisms). However, tailored implants with unusual and personalized shapes and sizes are often required for repairing large cranial, maxillary or facial bone defects.

On the other hand, slurries or fluid pastes of calcium phosphate cements can be easily formed into practically any desired shape by cast moulding before setting, without significant shrinkage or expansion. One of the more simple and inexpensive calcium phosphate cements is that based on $\beta$-TCP/ $\mathrm{H}_{3} \mathrm{PO}_{4}$, formerly developed and studied by Bohner et al. ${ }^{13}$ The setting occurring in this kind of cement results from the dissolution of $\beta$-TCP and the precipitation of an entanglement of dicalcium phosphate dihydrate (DCPD) crystals, which bridge the remaining particles of $\beta$-TCP, as represented in Eq. $1^{13-15}$.

$$
\beta-\mathrm{Ca}_{3}\left(\mathrm{PO}_{4}\right)_{2(\mathrm{~s})}+\mathrm{H}_{3} \mathrm{PO}_{4(\mathrm{aq})}+6 \mathrm{H}_{2} \mathrm{O} \rightarrow 3 \mathrm{CaHPO}_{4} \cdot 2 \mathrm{H}_{2} \mathrm{O}_{(\mathrm{s})}
$$

The main limitations of $\beta$-TCP/DCPD cement for clinical applications are its excessively high in vivo resorption rate, and the low initial $\mathrm{pH}$ and strength ${ }^{16}$.

*e-mail:rgc@biomat.uh.cu 
Another way of converting powders and coatings of DCPD into apatite is by hydrolysis in aqueous $\mathrm{CaCO}_{3}{ }^{17}$, $\mathrm{NH}_{4} \mathrm{OH}{ }^{17,18}, \mathrm{KOH}^{18}, \mathrm{NaOH}^{18}$, ammonium and alkaline fluorides ${ }^{19}, \mathrm{Na}_{2} \mathrm{HPO}_{4}{ }^{20}$, and in modified and un-modified Hank balanced solutions ${ }^{21,22}$. An example of this is the work of Fulmer and Brown where finely divided DCPD was converted into calcium deficient hydroxyapatite (CDHA) by hydrolysis over $16 \mathrm{~h}$ in $1 \mathrm{M} \mathrm{Na}_{2} \mathrm{HPO}_{4}$ at $60{ }^{\circ} \mathrm{C}$, as showed by Eq. $2^{20}$.

$$
\begin{aligned}
& (10-\mathrm{x}) \mathrm{CaHPO}_{4} \cdot 2 \mathrm{H}_{2} \mathrm{O}_{(\mathrm{s})}+(4-\mathrm{x}) \mathrm{Na}_{2} \mathrm{HPO}_{4(\mathrm{aq})} \rightarrow \\
& \mathrm{Ca}_{10-\mathrm{x}}\left(\mathrm{HPO}_{4}\right)_{\mathrm{x}}\left(\mathrm{PO}_{4}\right)_{6-\mathrm{x}}(\mathrm{OH})_{2-\mathrm{x}(\mathrm{s})}+(8-2 \mathrm{x}) \mathrm{NaH}_{2} \mathrm{PO}_{4(\mathrm{aq})}+(18-\mathrm{x}) \mathrm{H}_{2} \mathrm{O}
\end{aligned}
$$

The hydrolysis of DCPD, if conducted in $\mathrm{NaCOOCH}_{3}$ solution or in solutions containing low levels of $\mathrm{Ca}^{2+}$ ions, at $\mathrm{pH} 7$ or 7.5 , and at 25,37 , or $60^{\circ} \mathrm{C}$, may also produce octacalcium phosphate (OCP), probably in accordance with Eq. $3^{23}$.

$$
\begin{aligned}
& 8 \mathrm{CaHPO}_{4} \cdot 2 \mathrm{H}_{2} \mathrm{O}_{(\mathrm{s})}+2 \mathrm{Na}_{2} \mathrm{HPO}_{4(\mathrm{aq})} \rightarrow \\
& \mathrm{Ca}_{8} \mathrm{H}_{2}\left(\mathrm{PO}_{4}\right)_{6} \cdot 5 \mathrm{H}_{2} \mathrm{O}_{(\mathrm{s})}+4 \mathrm{NaH}_{2} \mathrm{PO}_{4(\mathrm{aq})}+11 \mathrm{H}_{2} \mathrm{O}
\end{aligned}
$$

OCP is a well-recognized precursor of apatite, which gradually transforms into apatite under the conditions of $\mathrm{pH}$, ionic concentration, and temperature existing in physiological fluids. Both, CDHA and OCP are more insoluble and have a lower resorption rate in vivo than DCPD. Besides, they produce an almost neutral $\mathrm{pH}$ in an aqueous environment, differently than DCPD which can induce some necrosis because of its acidic character ${ }^{23}$.

Taking into account the above points, it should be possible to employ $\beta-\mathrm{TCP} / \mathrm{H}_{3} \mathrm{PO}_{4}$ cement as a starting material for the preparation of calcium phosphate monoliths of $\mathrm{DCPD} / \beta$-TCP by mould casting and setting, and then to transform the DCPD constituent of the cement into a more biostable and biocompatible form of calcium phosphate, such as CDHA or OCP, by hydrolysis in $\mathrm{Na}_{2} \mathrm{HPO}_{4}$ aqueous solution. In this way it would be possible to manufacture a wide range of monolithic calcium phosphate bone implants with complex shapes and large sizes. The preliminary development and results of such a procedure are presented in this work.

\section{Experimental}

\subsection{Materials}

$\beta$-TCP was synthesized by titration at room temperature of $0.62 \mathrm{~mol} \mathrm{CaO}$ (P.A., Reachim), which had been previously heated at $800{ }^{\circ} \mathrm{C}$ for $2 \mathrm{~h}$, in $1 \mathrm{l}$ of commercial sucrose (20 wt.\%/vol.), with 11 of $0.40 \mathrm{M} \mathrm{H}_{3} \mathrm{PO}_{4}$ (P.A., Merck, $0.50 \mathrm{l} / \mathrm{h}$ ). The precipitate was aged in the mother liquor for $24 \mathrm{~h}$, filtered, washed with water, oven dried, and heated at $1000{ }^{\circ} \mathrm{C}$ for $8 \mathrm{~h}$. The product was divided into two portions. One portion (coarse) was sieved using $160 \mu \mathrm{m}$ mesh. The other portion (fine) was ball-milled in ethanol to a mean particle size of $2.5 \mu \mathrm{m}$.

The liquid (L) employed for the preparation of the cements was a solution of $\mathrm{H}_{3} \mathrm{PO}_{4} 2.0 \mathrm{M}$ and $\mathrm{Na}_{3} \mathrm{C}_{6} \mathrm{H}_{5} \mathrm{O}_{7} .2 \mathrm{H}_{2} \mathrm{O}$ (P.A., Riedel-de Häen) $0.08 \mathrm{M}^{14,15}$.

$\mathrm{Na}_{2} \mathrm{HPO}_{4}$ (P.A., Merck) 0.5 M and 1.0 M were employed as hydrolysing solutions ${ }^{20}$.

\subsection{Preparation of cement samples}

The liquid-to-powder ratios (L/P) employed were 0.8 and $1.0 \mathrm{ml} / \mathrm{g}$. The $\beta$-TCP powder was kneaded with $\mathrm{L}$ for $30 \mathrm{~s}$, and the slurry was cast into discs (of height $6 \mathrm{~mm}$ and diameter $12 \mathrm{~mm}$ ) or cylinders (of height $12 \mathrm{~mm}$ and diameter $6 \mathrm{~mm}$ ). The samples were left to set and age at $100 \%$ relative humidity and room temperature for $24 \mathrm{~h}$, and then dried at room temperature in air.

\subsection{Hydrolysis experiments}

Discs or cylinders of dried cement were placed into glass flasks and $0.5 \mathrm{M}$ or $1.0 \mathrm{M} \mathrm{Na}_{2} \mathrm{HPO}_{4}$ solution was added in a ratio of $5 \mathrm{ml} / \mathrm{g}$ of cement. The flasks were immediately tightly sealed and placed in a thermostatic bath at $60 \pm 1{ }^{\circ} \mathrm{C}$, over different periods of time. After the required period of time expired, the samples were removed from the flasks, immersed in fresh acetone for $30 \mathrm{~min}$ to stop the hydrolysis, and then dried in air at room temperature. In some experiments the $\mathrm{pH}$ of the hydrolysing solution was continuously monitored.

\subsection{Methods of characterisation}

The mineralogical composition of starting powder, set cement, and hydrolysis products was studied by means of a Siemens D-500 X-ray Diffractometer, using CuK $\mathrm{C}_{\alpha}$, Ni-filtered radiation. An angular sweeping rate of $0.05^{\circ}(2 \theta) / \mathrm{s}$ was employed in the case of the patterns shown in Figs. 1 and 2 , and step size of $0.02^{\circ}(2 \theta)$ and counting time of $10 \mathrm{~s}$ for patterns in Fig. 3 .

Compressive strength was measured using a servo-hydraulic universal testing machine MTS Bionix 858 with a crosshead speed of $1 \mathrm{~mm} / \mathrm{min}$. At least six cylinders were tested for each specimen.

The microstructure of fracture surface of set and hydrolysed cements was observed with a Jeol JS 6300 scanning electron microscope. Prior to analysis the samples were coated with a gold layer.

\section{Results and Discussion}

The XRD pattern of the starting powder (see Fig. 1) corresponded to well-crystallized $\beta$-TCP (JCPDF 9-169) this being the main crystalline phase present. A minor amount of $\mathrm{Ca}_{2} \mathrm{P}_{2} \mathrm{O}_{7}$ (JCPDF 9-346) was also found.

The slurries resulting from mixing $\beta$-TCP and $\mathrm{L}$, 


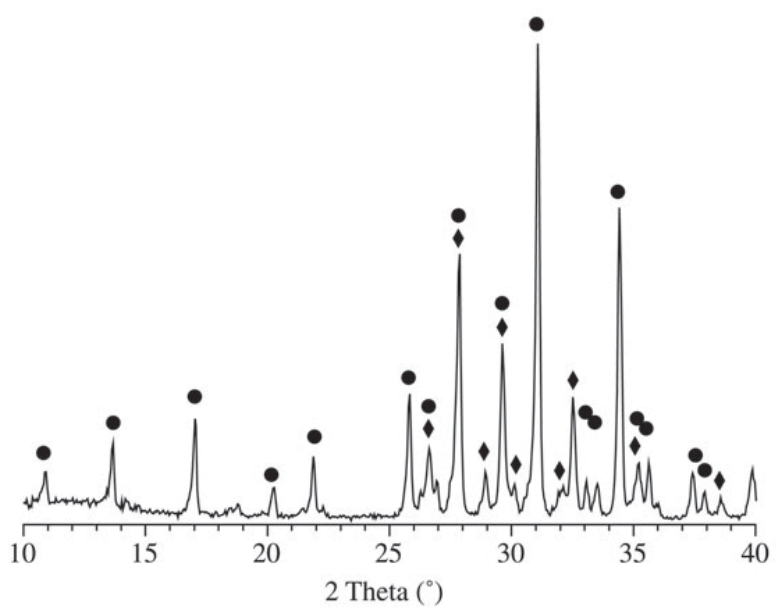

Figure 1. X-ray powder diffraction pattern of the starting $\beta$-TCP powder (fine). •: $\beta$-TCP (JCPDF 9-169); $: \mathrm{Ca}_{2} \mathrm{P}_{2} \mathrm{O}_{7}$ (JCPDF 9-346).

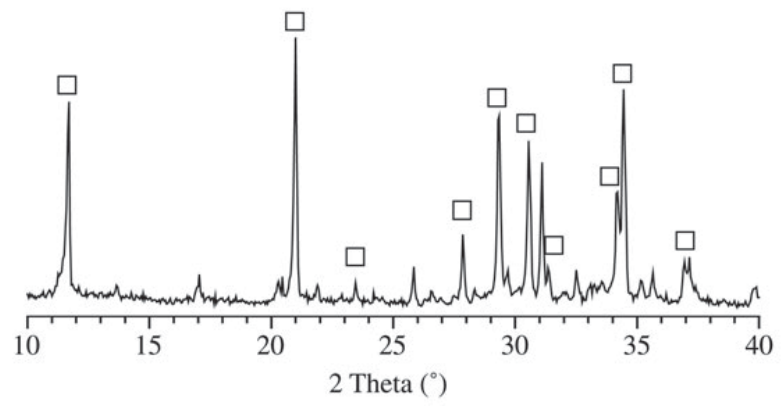

Figure 2. X-ray powder diffraction pattern of the resulting cement after mixing $\beta$-TCP (fine) and $\mathrm{L}(\mathrm{P} / \mathrm{L}=1.0 \mathrm{ml} / \mathrm{g}$ ), setting and ageing. $\square$ : $\mathrm{CaHPO}_{4} \cdot 2 \mathrm{H}_{2} \mathrm{O}$ (JCPDF 9-77).

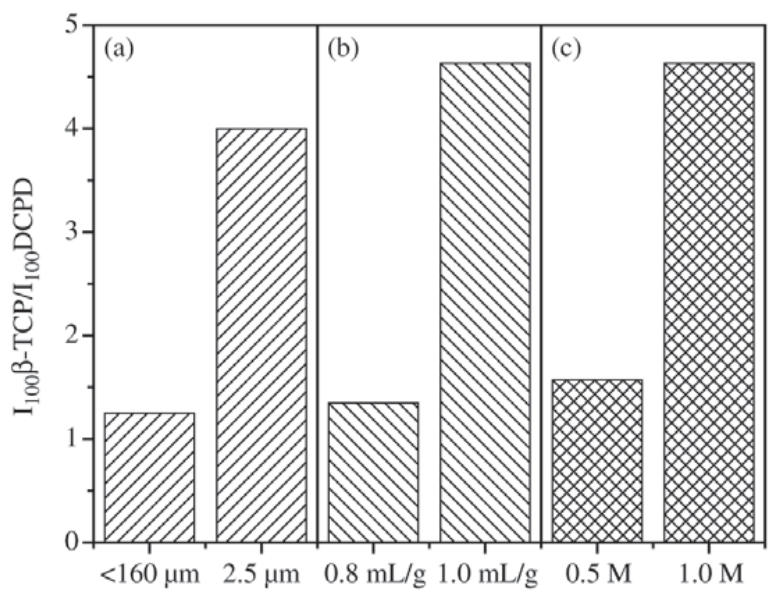

Figure 3. Intensity ratios of the $I_{100} \beta$-TCP and $I_{100}$ DCPD X-ray diffraction peaks for cements hydrolysed at $60{ }^{\circ} \mathrm{C}$ for $16 \mathrm{~h}$. (a) prepared with coarse and fine $\beta-\mathrm{TCP}, \mathrm{L} / \mathrm{P}=1.0 \mathrm{ml} / \mathrm{g}$, and hydrolysed in $1.0 \mathrm{M} \mathrm{Na}_{2} \mathrm{HPO}_{4}$; (b) prepared with fine $\beta$-TCP, L/P of 0.8 and $1.0 \mathrm{ml} / \mathrm{g}$, and hydrolysed in $1.0 \mathrm{M} \mathrm{Na}_{2} \mathrm{HPO}_{4}$; (c) prepared with fine $\beta-\mathrm{TCP}, \mathrm{L} / \mathrm{P}=1.0 \mathrm{ml} / \mathrm{g}$, and hydrolysed in 0.5 and $1.0 \mathrm{M} \mathrm{Na}_{2} \mathrm{HPO}_{4}$. irrespectively of the $\mathrm{P} / \mathrm{L}$ employed, set into solid bodies in approximately 3-4 min. This time permitted the mixing and casting of cements into moulds. In this work $0.08 \mathrm{M}$ sodium citrate was used as retardant additive, in accordance with previous reports by Bohner et al., who exhaustively studied the effect of citrate ion and other setting retardants on this cement ${ }^{14,15}$. The use of a higher concentration of citrate ion in L would increase the setting time even more. However, in this work this concentration was kept to a minimum in order to reduce the inhibitory effect of citrate ion on the crystallization of apatite ${ }^{23}$.

The X-ray diffraction pattern of cement prepared from $\beta$-TCP (fine) with L/P $1.0 \mathrm{ml} / \mathrm{g}$ is presented in Fig. 2. Beside the characteristic peaks of $\beta$-TCP and $\mathrm{Ca}_{2} \mathrm{P}_{2} \mathrm{O}_{7}$, already identified in the starting powder, new peaks of DCPD (JCPDF 9-77) appeared as result of the reaction represented in Eq. 1. Cements prepared with other particle sizes and $\mathrm{L} / \mathrm{P}$ used in this work presented very similar X-ray diffraction patterns.

The hydrolysis of DCPD present in a block of cement is a heterogeneous process; therefore its rate should depend on the area of the liquid/solid interface and on the diffusion rate of fresh hydrolysing solution through pores and channels into the interior of the block. Thus, high cement porosity should favour the rate of hydrolysis. The powder particle size and L/P ratio are factors affecting the cement porosity ${ }^{24}$. The concentration of the hydrolysing species, i.e. $\mathrm{Na}_{2} \mathrm{HPO}_{4}$, may also affect the reaction rate.

To establish the effect on the conversion of DCPD to CDHA or/and OCP by the particle size of the starting $\beta$-TCP powder, hydrolysis experiments were carried out on discs of cements prepared from coarse and fine $\beta$-TCP. The L/P used was $1.0 \mathrm{ml} / \mathrm{g}$ and the concentration of the $\mathrm{Na}_{2} \mathrm{HPO}_{4}$ hydrolysing solution was $1.0 \mathrm{M}$. The hydrolysis was stopped after $16 \mathrm{~h}$, and the outer layer $(\approx 1.5 \mathrm{~mm})$ of the discs was sliced off. The X-ray diffraction patterns of the powdered central portion of the discs were recorded, and the integrated intensities of peaks at $20.9^{\circ}(2 \theta)$ for DCPD $(d=4.24 \AA$, $\left.\mathrm{I}_{100}, 021\right)$, and $31.0^{\circ}(2 \theta)$ for $\beta-\mathrm{TCP}\left(\mathrm{d}=2.88 \AA, \mathrm{I}_{100}, 0210\right)$ were measured. The intensity ratios $\mathrm{I}_{100} \mathrm{DCPD} / \mathrm{I}_{100} \beta$-TCP were calculated for both of the hydrolysed cements, as shown in Fig. 3a. As the intensity of $\beta$-TCP may be considered to be invariable during the hydrolysis in $\mathrm{Na}_{2} \mathrm{HPO}_{4}$, the ratio $\mathrm{I}_{100} \mathrm{DCPD} / \mathrm{I}_{100} \beta$-TCP can be used as an index of the amount of DCPD present in the sample ${ }^{25}$.

Similar experiments were carried out in which the effect of $\mathrm{L} / \mathrm{P}$ and the concentration of $\mathrm{Na}_{2} \mathrm{HPO}_{4}$ on the transformation of DCPD was studied. The results are shown in Figs. $3 b$ and $3 c$.

It can be seen in Fig. 3 that the most rapid depletion of DCPD as result of hydrolysis through reactions of Eqs. 2 and/or 3 occurs in the case of those cements made of fine $\beta$-TCP with $\mathrm{L} / \mathrm{P}$ of $1.0 \mathrm{ml} / \mathrm{g}$ and hydrolysed in $1.0 \mathrm{M}$ 
$\mathrm{Na}_{2} \mathrm{HPO}_{4}$. These results can be explained in terms of the higher surface area of the DCPD crystals when a smaller particle size is employed, the increasing of porosity with $\mathrm{L} / \mathrm{P}$ ratio, and the diminution of $\Delta \mathrm{G}$ for the global hydrolysis reaction with increase of concentration of the hydrolysing species. These optimised conditions were employed in all subsequent experiments.

Cement samples were hydrolysed for periods of 5, 24, 48,112 and $192 \mathrm{~h}$ in order to study the kinetics of the conversion of DCPD. After each period, hydrolysis was stopped and the compressive strength of the dried hydrolysed pieces was determined. The results of the strength determinations are shown in Fig. 4.

The material remaining from the strength tests was triturated (without removing the outer layer) and the resulting powder was examined by X-ray diffraction. The corresponding X-ray diffractograms are shown in Fig. 5.

Compressive strength fell slightly from 6.9 to $5.8 \mathrm{MPa}$ after $5 \mathrm{~h}$ of hydrolysis, and increased again on extending the hydrolysis time, reaching $16.2 \mathrm{MPa}$ at a reaction time of $112 \mathrm{~h}$. The compressive strength of the hydrolysed materials is similar to that of cancellous bone (2-12 MPa) and coralline macroporous hydroxyapatite $(2.5-5.4 \mathrm{MPa})^{1}$. The initial drop of strength with hydrolysis could be attributed to partial dissolution of the large DCPD crystals originally present in the cement before hydrolysis, as shown in Fig. 6a.

As the hydrolysis progressed, the intensities of the $\mathrm{X}$-ray diffraction peaks of DCPD decreased while new peaks corresponding to apatite, presumably CDHA according to Fulmer and Brown ${ }^{20}$, and OCP appeared (Fig. 5). After $5 \mathrm{~h}$ (Fig. 5a), only CDHA and the phases already identified in

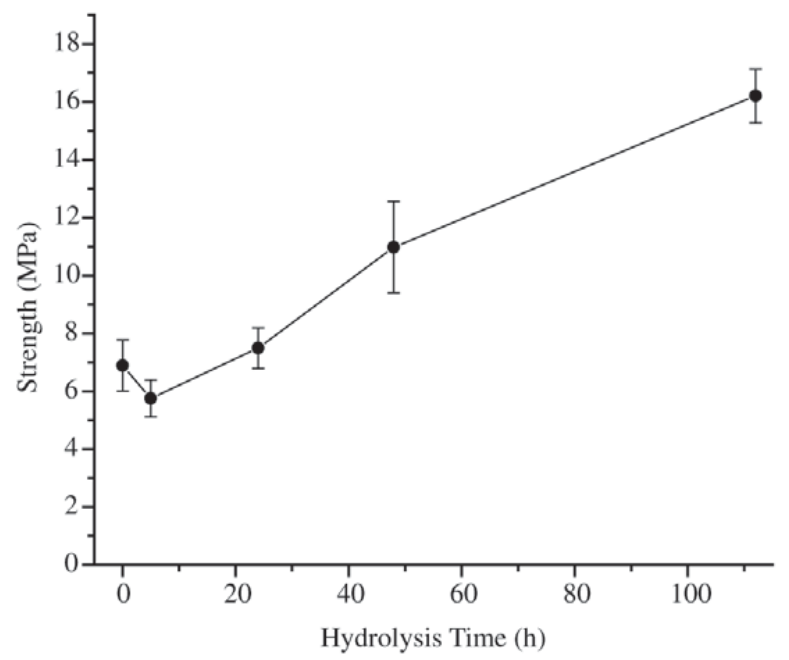

Figure 4. Variation of compressive strength with hydrolysis time. (Cement: fine $\beta$-TCP; $\mathrm{L} / \mathrm{P}=1.0 \mathrm{ml} / \mathrm{g} ; 1.0 \mathrm{M} \mathrm{Na}_{2} \mathrm{HPO}_{4}$ ). the starting cement (Fig. 2) were present. After $24 \mathrm{~h}$ peaks of OCP appeared and the intensities of the apatite peaks increased, while the DCPD signals weakened. After $112 \mathrm{~h}$, DCPD had been completely transformed into CDHA or OCP, and no additional formation of CDHA or OCP was observed at $192 \mathrm{~h}$. The $\mathrm{NaH}_{2} \mathrm{PO}_{4}$ formed by reactions of Eqs. 2 and 3 could not be completely removed by washing with acetone and was detected in all hydrolysed samples as $\mathrm{NaH}_{2} \mathrm{PO}_{4} \cdot \mathrm{H}_{2} \mathrm{O}$.

The micrograph of the fracture surface after $5 \mathrm{~h}$ of hydrolysis is shown in Fig. 6b. This is similar to the micrograph of the fracture surface before hydrolysis (Fig. 6a), with large plate-like crystals of DCPD embedding the remaining granules of $\beta$-TCP. However, in Fig. $6 \mathrm{~b}$ it can be seen that nanometric crystals of CDHA have completely

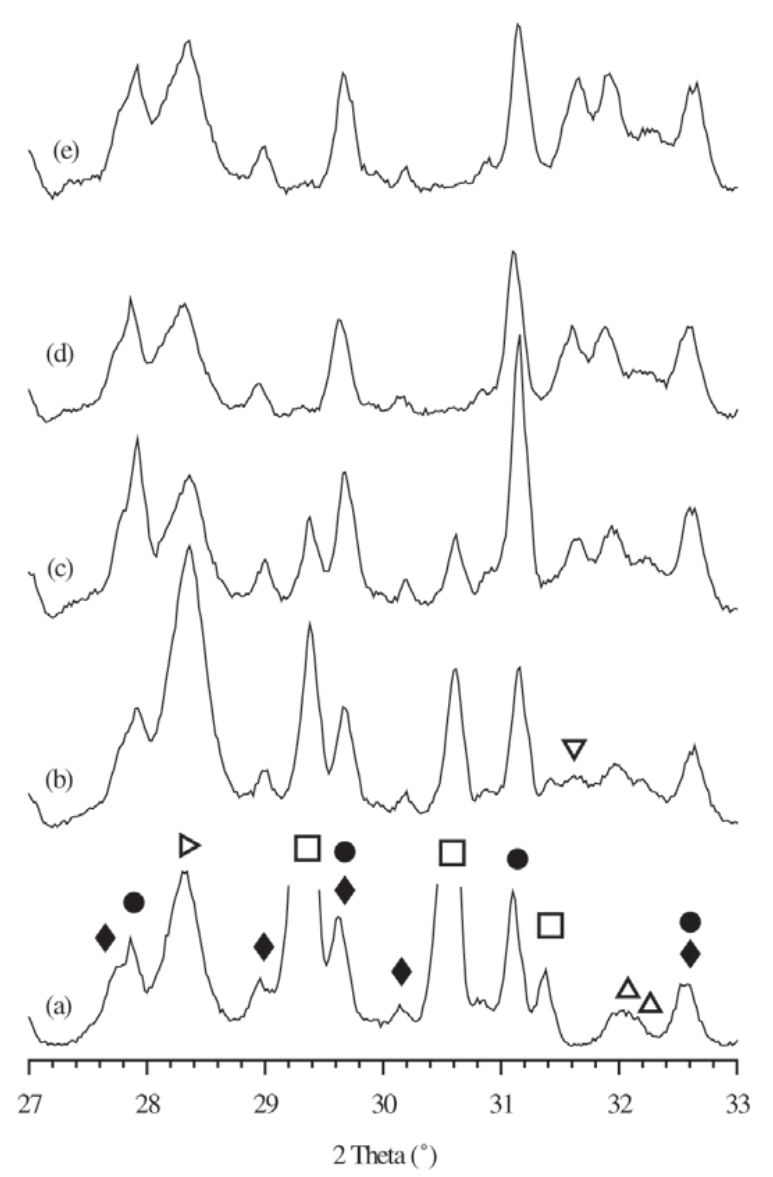

Figure 5. X-Ray diffraction patterns of cement (fine $\beta$-TCP; $\mathrm{L} / \mathrm{P}=1.0 \mathrm{ml} / \mathrm{g} ; 1.0 \mathrm{M} \mathrm{Na}_{2} \mathrm{HPO}_{4}$ ) hydrolysed for different periods of time: (a) $5 \mathrm{~h}$; (b) $24 \mathrm{~h}$; (c) $48 \mathrm{~h}$; (d) $112 \mathrm{~h}$; (e) $192 \mathrm{~h}$.

-: $\beta$-TCP (JCPDF 9-169), $\bullet: \mathrm{Ca}_{2} \mathrm{P}_{2} \mathrm{O}_{7}$ (JCPDF 9-346), ㅁ: $\mathrm{CaHPO}_{4} \cdot 2 \mathrm{H}_{2} \mathrm{O}$ (JCPDF 9-77), $\triangle: \mathrm{Ca}_{10}\left(\mathrm{PO}_{4}\right)_{6}(\mathrm{OH})_{2}$ (JCPDF9-432), $\nabla: \mathrm{Ca}_{4} \mathrm{H}\left(\mathrm{PO}_{4}\right)_{3} \cdot 2 \cdot 5 \mathrm{H}_{2} \mathrm{O}(\mathrm{JCPDF} 44-778), \square: \mathrm{NaH}_{2} \mathrm{PO}_{4} \cdot \mathrm{H}_{2} \mathrm{O}$ (JCPDF 11-651). 
coated the partially dissolved DCPD crystals. At this stage, the transformation of DCPD into CDHA has only reached the outer layer of the sample, as shown in the low magnification micrograph of Fig. 6c. This confirms the results of $\mathrm{X}$-ray diffraction where CDHA was the only new phase formed after $5 \mathrm{~h}$ of reaction (Fig. 5a).

At $48 \mathrm{~h}$ the microstructure of the fracture surface of hydrolysed cement is quite different from that observed at $5 \mathrm{~h}$, as can be observed in Figs. 7a and 7b. Aggregates of short plates, very similar to those described for OCP by $\mathrm{LeGeros}^{23}$, are found near to the surface of the sample after hydrolysis for $48 \mathrm{~h}$ (Fig. 7a). However, at the centre of the sample (Fig. 7b) the same microstructure as described for the non-hydrolysed cement in Fig. 7a, is observed. This finding suggests that hydrolysis proceeds from the outer to the inner portion of the piece, and that the rate depends on rate of diffusion of the hydrolysing solution into the solid mass. The formation of OCP instead of CDHA can be explained by the variation in $\mathrm{pH}$ of the hydrolysis media shown in Fig. 8. In the first stage of hydrolysis, $\mathrm{pH}$ is clearly alkaline or neutral; hence hydrolysis via the reaction of Eq. 2 is favoured. However, $\mathrm{pH}$ drops below 7 after $24 \mathrm{~h}$ of hydrolysis, and formation of OCP through the reaction of Eq. 3 becomes predominant under such conditions of slightly acidic $\mathrm{pH}$ and low concentration of $\mathrm{Ca}^{2+}$ ions ${ }^{23}$.

After $112 \mathrm{~h}$ of hydrolysis the fracture surfaces near to the outer layer (Fig. 7c) and in the inner core of the sample (Fig. 7d) have the same appearance and both consist of the aggregates of OCP short-plate crystals. This indicates that the hydrolysis front reached the centre of the sample.

An attempt to relate microstructure to strength changes during hydrolysis suggests that entanglement of crystals is the main responsible for strength. In this way, the large platelike DCPD crystals embedding $\beta$-TCP granules that exist in the set cement are very entangled and provide the material with higher strength than the smaller CDHA crystals grown onto partially dissolved DCPD with a low entanglement degree, formed in the first stage of hydrolysis. The strengthening observed with hydrolysis time is a result of the more clogged microstructure provided by the aggregates of plates of OCP effectively entangled, and developed in the medium and final stages of hydrolysis.

According to Bohner et al., a completion of $92.6 \%$ of the reaction of Eq. 1 is obtained during the setting of a cement of $\beta-\mathrm{TCP} / \mathrm{H}_{3} \mathrm{PO}_{4}$ containing $2 \mathrm{M} \mathrm{H}_{3} \mathrm{PO}_{4}$ and $0.08 \mathrm{M}$ citric acid in the liquid ${ }^{15}$. Assuming the same conversion for the cement studied in this work, and considering that half of the DCPD hydrolyses into CDHA, and the remaining into OCP, the approximate composition of the monoliths so obtained is $30 \mathrm{wt} . \% \beta$-TCP, 49 wt.\% OCP, and 21 wt.\% CDHA.
At the present time, the authors are carrying out further studies of the effect of conversion, L/P, powder particle size in the initial cement, and composition of the hydrolysing media, on the properties of calcium phosphate monoliths obtained by this procedure.

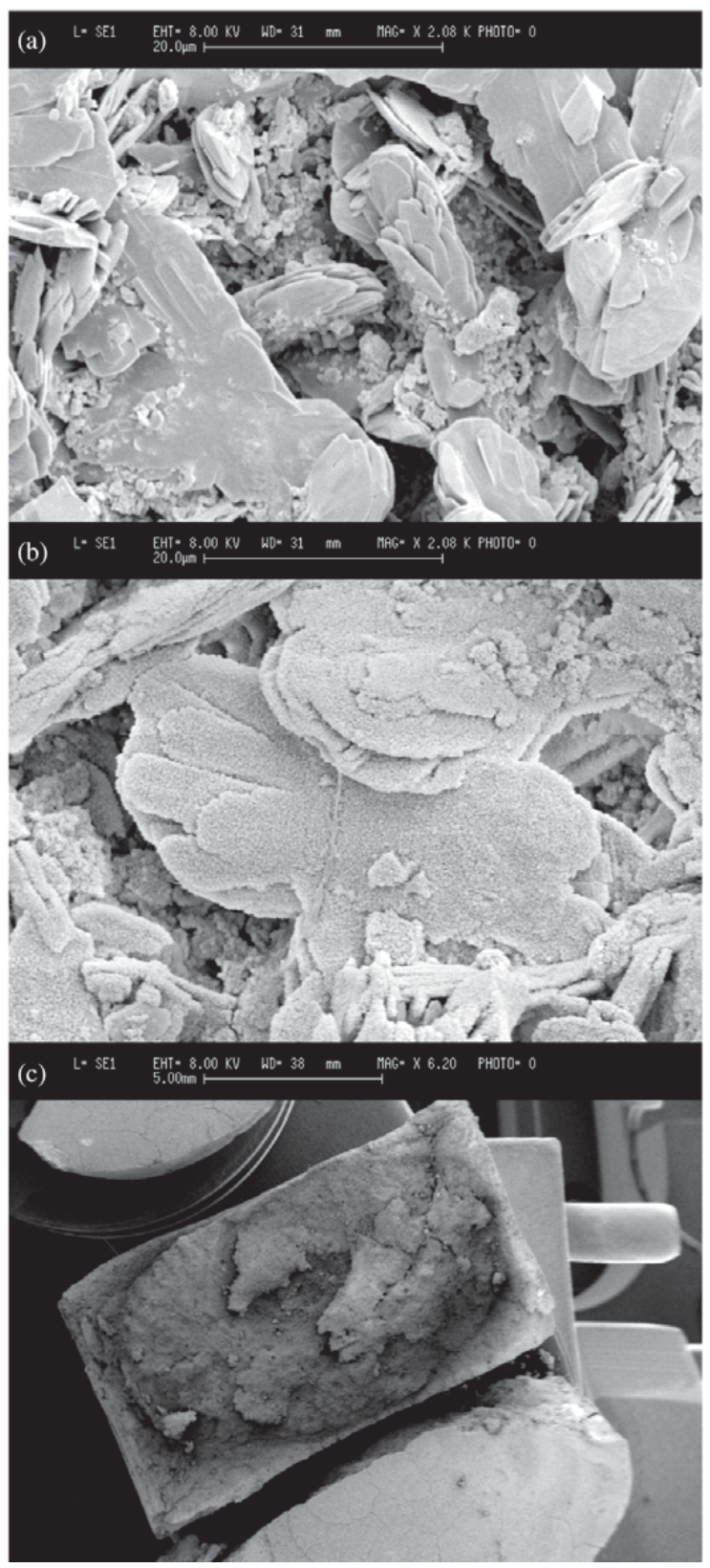

Figure 6. SEM micrographs of the fracture surface of cement: (a) before hydrolysis; (b) after $5 \mathrm{~h}$ of hydrolysis; (c) b at low magnification. (Cement: fine $\beta$-TCP; $\mathrm{L} / \mathrm{P}=1.0 \mathrm{ml} / \mathrm{g} ; 1.0 \mathrm{M} \mathrm{Na}_{2} \mathrm{HPO}_{4}$ ). 

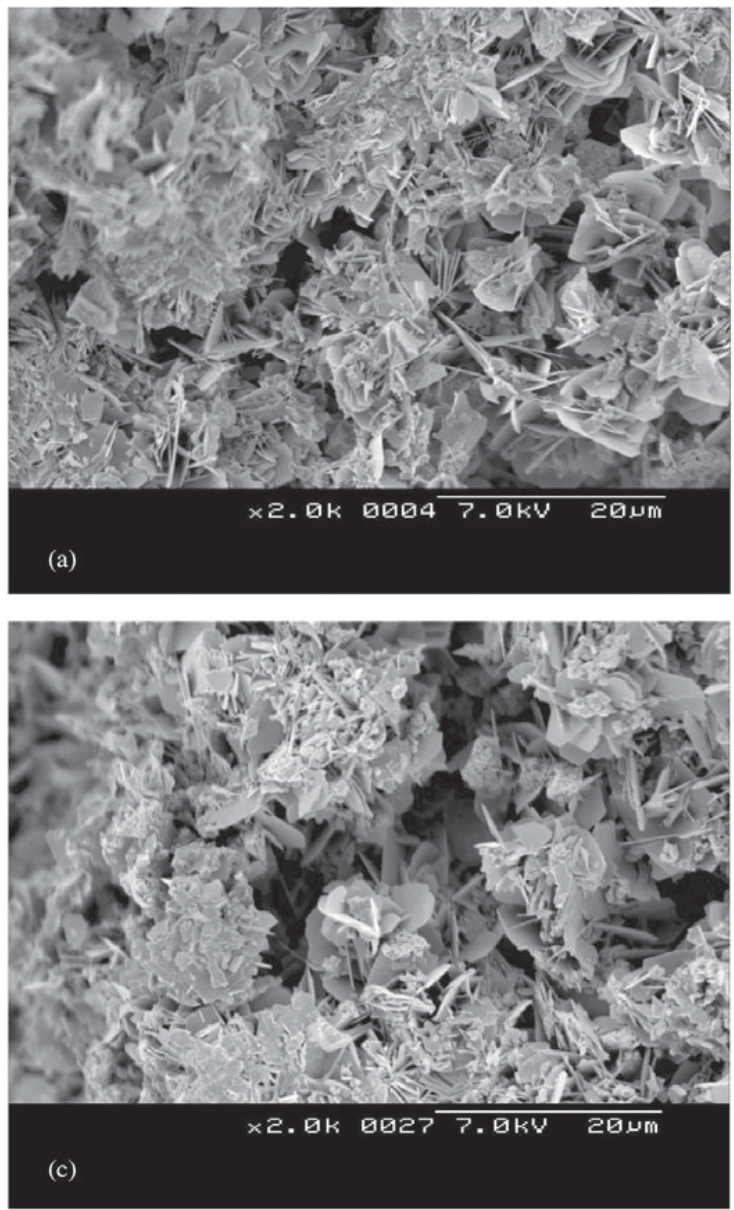
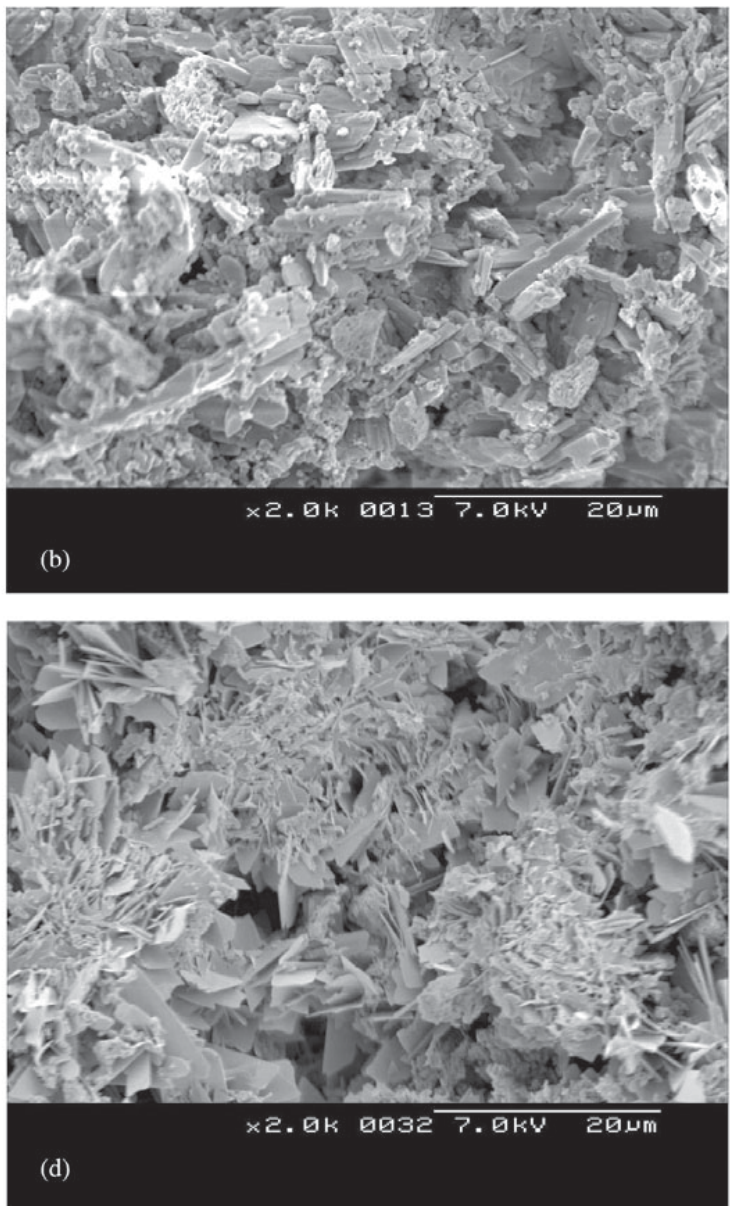

Figure 7. SEM micrographs of the fracture surface of cement after 48 and $112 \mathrm{~h}$ of hydrolysis in different parts of the sample: (a) $48 \mathrm{~h}$, near to the outer surface; (b) $48 \mathrm{~h}$, at the centre; (c) $112 \mathrm{~h}$, near to the outer surface; (d) $112 \mathrm{~h}$, at the centre. (Cement: fine $\beta$-TCP; $\mathrm{L} / \mathrm{P}=1.0 \mathrm{ml} / \mathrm{g} ; 1.0 \mathrm{M} \mathrm{Na}_{2} \mathrm{HPO}_{4}$ ).

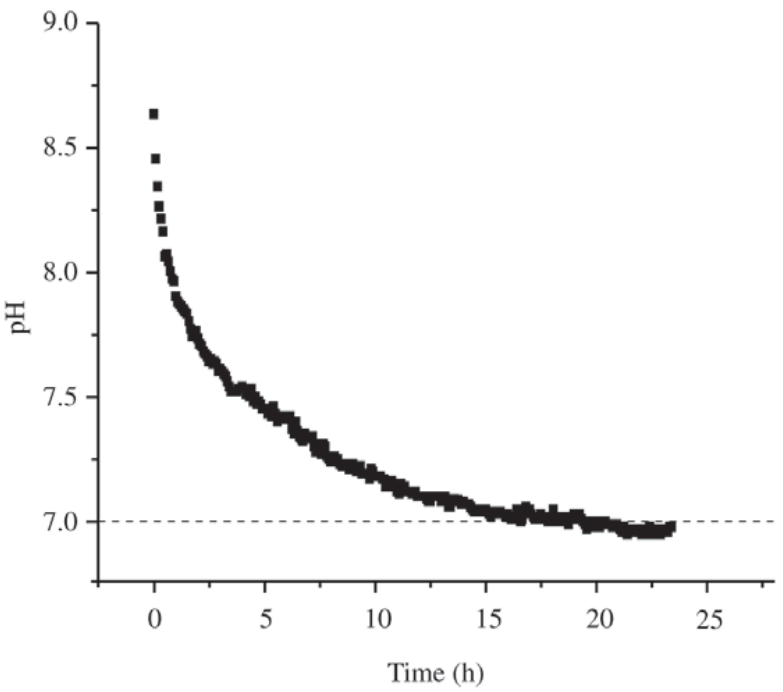

Figure 8. Variation of $\mathrm{pH}$ with hydrolysis time. (Cement: fine $\beta$-TCP; $\left.\mathrm{L} / \mathrm{P}=1.0 \mathrm{ml} / \mathrm{g} ; 1.0 \mathrm{M} \mathrm{Na}_{2} \mathrm{HPO}_{4}\right)$.

\section{Conclusions}

By following the simple and low cost methods described above it is possible to obtain monoliths of biocompatible calcium phosphates with practically any desired shape and size. Implants prepared in this way possess composition and strength which make them suitable for bone remodelling or replacement in low bearing applications.

\section{Acknowledgements}

Authors recognize the financial support from the Projects "Production of acrylic- and calcium phosphates-based cements" of the Center of Co-operation for Development of the Polytechnique University of Catalunya, Spain, and "Alma Mater 2000. Ocular, Spinal and Maxilla-Facial Implants" of the Universidad de La Habana. Dr. Christopher Waring is also gratefully recognised for the revision of the English language. This paper is a result of the CYTED Network VIII.J "Biomateriales para la salud". 


\section{References}

1. Hench, L.L.; Wilson, J. (Eds.), An Introduction to Bioceramics, World Scientific, Singapore, Malaysia, 1993.

2. Raynaud, S.; Champion, E.; Lafon, J.P.; BernacheAssollant, D. Biomaterials, v. 23, n. 4, p. 1081-1089, 2002.

3. Slózarczyk, A.; Paskiewicz, Z. Euro Ceramics VII, PT 1-3, v. 206-2, p. 1621-1624, 2002.

4. Rodriguez-Lorenzo, L.M.; Vallet-Regí, M.; Ferreira, J.M.F. Biomaterials, v. 22, n. 6, p. 583-588, 2001.

5. Zyman, Z.Z.; Ivanov, I.G.; Glushko, V.I.; Kijko, S.M.; Surov, Y.N.; Chmutov, V.M. J. Biomed. Mater. Res., v. 46, n. 2, p. 135-140, 1999.

6. Rao, R.R.; Kannan, T.S. J. Am. Ceram. Soc., v. 84, n. 8, p. 1710-1716, 2001.

7. Rodriguez-Lorenzo, L.M.; Vallet-Regí, M.; Ferreira, J.M.F. Biomaterials, v. 22, n. 13, p. 1847-1852, 2001.

8. Carotenuto, G.; Spagnuolo, G.; Ambrosio, L.; Nicolais, L. J. Mater. Sci. Mater. Med., v. 10, n. 10-11, p. 671-676, 1999.

9. Vaz, L.; Lopes, A.B.; Almeida, M. J. Mater. Sci. Mat. Med., v. 10, n. 4, p. 239-242, 1999.

10. Liu, D.M., Ceram. Int., v. 24, n. 6, p. 441-446, 1998.

11. de Campos, M.; Bressiani, A.H.; Bioceramics 14, Key Eng. Mat., v. 218-2, p. 171-174, 2002.

12. Sepulveda, P.; Binner, J.G.P.; Rogero, S.O.; Higa, O.Z.; Bressiani, J.C. J. Biomed. Mater. Res., v. 50, n. 1, p. $27-$ 34, 2000.

13. Bohner, M.; Lemaître, J.; Ring, T.A. in: Proceedings of the Third Euro-Ceramics Conference, Madrid, September 1993, Durán, P.; Fernández, J.F. (Eds.), Faenza
Editrice Ibérica, Arganda del Rey, Spain, p. 95, 1993.

14. Bohner, M.; Lemaître, J.; Ring, T.A. J. Am. Ceram. Soc., v. 79, n. 6, p. 1427-1434, 1996.

15. Bohner, M.; Merkle, H.P.; Van Landuyt, P.; Trophardy, G.; Lemaître, J. J. Mater. Sci. Mater. Med., v. 11, p. 111116, 2000.

16. Driessens, F.C.M.; Planell, J.A.; Boltong, M.G.; Khairum, I.; Ginebra, M.P. Proc. Inst. Mech. Engrs., v. 212(Part H), p. 427-435, 1998.

17. Kim, S.R.; Park, S.J. in: Ceramic Transactions Vol.22: Ceramic Powder Science III, Messing, G.L.; Hirano, S.; Hausner, H. (Eds.), American Ceramic Society, Westerville, OH, p. 201, 1991.

18. Prado da Silva, M.H.; Lima, J.H.C.; Soares, G.A.; Elias, C.N.; de Andrade, M.C.; Best, S.M.; Gibson, I.R. Surf. Coat. Technol., v. 137, p. 270-276, 2001.

19. Martin, R.I.; Brown, P.W. J. Crystal Growth, v. 183, p. 417-426, 1998.

20. Fulmer, M.T.; Brown, P.W. J. Mater. Sci. Mater. Med., v. 9, p. 1997-2002, 1998.

21. Kumar, M.; Xie, J.; Chittur, K.; Riley, C. Biomaterials, v. 20, p. $1389-1399,1999$.

22. Kumar, M.; Dasarathy, H.; Riley, C. J. Biomed. Mater. Res., v. 45, p. 302-310, 1999.

23. LeGeros, R.Z. Calcium Phosphates in Oral Biology and Medicine, Karger, Basel, Switzerland, 1991.

24. Ishikawa, K.; Asaoka, K. J. Biomed. Mater. Res., v. 29, p. 1537-1543, 1995.

25. Ginebra, M.P.; Fernández, E.; De Maeyer, E.A.P.; Verbeeck, R.M.H.; Boltong, M.G.; Ginebra, J.; Driesssens, F.C.M.; Planell, J.A. J. Dent. Res., v. 76, n. 4, p. 905-912, 1997. 